\title{
The Degradation of $p$-Coumaryl Alcohol by Aspergillus flavus
}

\author{
By C. B. IYAYI $\dagger$ AND R. K. DART* \\ Microbiology Unit, Department of Chemistry, University of Technology, Loughborough, \\ Leicestershire LE11 3TU, U.K.
}

(Received 21 September 1981; revised 2 November 1981)

\begin{abstract}
Aspergillus flavus utilized p-coumaryl alcohol, one of the major constituents of lignin, as sole carbon source. The following compounds were isolated from the growth medium and identified by means of their melting points, IR, NMR and mass spectra: $p$-coumaric acid, $p$-hydroxybenzoic acid and protocatechuic acid. Culture filtrates from mycelium grown on $p-\left[1-{ }^{14} \mathrm{C}\right]$ coumaryl alcohol contained $p-\left[{ }^{14} \mathrm{C}\right]$ coumaric acid, $\beta$-hydroxy-( $p$-hydroxyphenyl) $\left[{ }^{14} \mathrm{C}\right.$ )propionic acid, ( $p$-hydroxybenzoyl) $\left[{ }^{14} \mathrm{C}\right]$ acetic acid and $\left[{ }^{14} \mathrm{C}\right]$ acetic acid. Oxidation of protocatechuic acid by crude cell-free extracts formed $\beta$-ketoadipic acid, which was isolated and characterized.
\end{abstract}

A pathway for the degradation of $p$-coumaryl alcohol by Aspergillus flavus is proposed.

\section{IN TR ODUCTION}

Lignin is one of the most important sources of renewable carbon in nature. Chemically, it is thought to be formed by the oxidative polymerization of the three substituted cinnamyl alcohols: $p$-coumaryl, coniferyl and sinapyl alcohols (Freudenberg \& Neish, 1968; Higuchi, 1971; Kirk, 1971). The biodegradation of lignin in nature is carried out mainly by fungi, especially the 'wood rotting' fungi; several authors (Cowling, 1961; Oglesby et al., 1967) have compiled extensive lists of such fungi. A few bacteria are also known to degrade lignin and lignin model compounds (Stanier \& Ornston, 1973; Kawakami, 1976, 1980; Fukuzumi, 1980).

Studies on the microbial degradation of lignin have made use of a series of model compounds which circumvent some of the problems associated with the use of native lignin (Ander \& Eriksson, 1978). The sequence of reactions leading from lignin to its monomers is controversial and the importance of monomers such as $p$-coumaryl alcohol in the degradation process is not fully understood.

Aspergillus flavus has been isolated from wood-rotting systems, and the metabolism of this organism is of considerable interest because of its ability to grow on a large variety of agricultural produce and synthesize a number of toxic compounds. This paper provides evidence for the degradation of $p$-coumaryl alcohol by $A$.flavus.

\section{METHODS}

Maintenance and growth of A. flavus. Aspergillus flavus CMI 15959 was obtained from the Commonwealth Mycological Institute, Ferry Lane, Kew, Surrey, U.K. It was maintained on slopes of the following medium: maltose, $38 \mathrm{~g}$; yeast extract, $2.5 \mathrm{~g}$; mycological peptone, $8 \mathrm{~g}$; malt extract, $2 \mathrm{~g}$; agar, $20 \mathrm{~g}$; water to $11 ; \mathrm{pH} 5.0$. It was subcultured at intervals of 2 weeks.

The fungus was grown in a medium comprising: $\mathrm{NaNO}_{3}, 5 \mathrm{~g} ; \mathrm{KH}_{2} \mathrm{PO}_{4}, 5 \mathrm{~g}$; Bacto-yeast extract, $0.1 \mathrm{~g}$; the appropriate carbon source at $6.25 \times 10^{-3} \mathrm{M}$; water to 11 . The $\mathrm{pH}$ was adjusted to 5.2 with $1 \mathrm{M}-\mathrm{NaOH}$ and medium dispensed in $100 \mathrm{ml}$ portions in 11 Erlenmeyer flasks.

† Present address: Department of Biochemistry, University of Benin, Benin City, Nigeria. 
Cultures required for quantitative growth experiments were inoculated with $1 \mathrm{ml}$ of spore suspensions containing approximately $10^{5}$ spores which had been prepared and harvested by the method of Dart (1975).

Cultures were incubated at $30^{\circ} \mathrm{C}$ under static conditions or shaken on an orbital incubator at $100 \mathrm{rev}$. $\mathrm{min}^{-1}$ at $30^{\circ} \mathrm{C}$ for $7 \mathrm{~d}$ unless otherwise stated.

Cultures were harvested by filtration when grown statically and by centrifugation when shake cultures were used for manometric studies. Quantitative growth measurements were made by dry weight determinations.

Cell-free extracts. Mycelial mats were harvested by filtration, washed twice with buffer and macerated by hand for $5 \mathrm{~min}$ with an equal weight of alumina beads in a chilled mortar. Sodium phosphate buffer $(0.025 \mathrm{M}) \mathrm{pH} 7.0$ was added and the mixture homogenized and centrifuged at $15000 \mathrm{~g}$ for $30 \mathrm{~min}$. The supernatant obtained was decanted and used immediately.

Protein determination. Protein was estimated by the method of Stickland (1951), using bovine serum albumin as standard.

Manometry. The oxygen consumption of both mycelial mats and cell-free extracts was determined using a Warburg apparatus (Umbreit et al., 1964) supplied by Braun (F. T. Scientific Instruments, Tewkesbury, U.K.). The temperature of incubation was $30^{\circ} \mathrm{C}$ and the gas phase was air. The total volume of liquid in the flasks was $3 \mathrm{ml}$ made up as follows. The main chamber contained $1.8 \mathrm{ml}$ mycelial suspension or mycelial extract (approx. $10 \mathrm{mg}$ protein) suspended in $0.5 \mathrm{~m}$-phosphate buffer $\mathrm{pH} 5.2$. The centre well contained $0.2 \mathrm{ml} 20 \%(\mathrm{w} / \mathrm{v}$ ) $\mathrm{KOH}$ and a small piece of filter paper. The reaction was started by tipping $1.0 \mathrm{ml}$ substrate $(5 \mu \mathrm{mol})$ from the side arm into the main compartment. Readings were taken at 10 min intervals.

Chemicals. The synthesis of $p$-coumaryl alcohol was carried out from $p$-coumaric acid by the method of $\mathrm{Li} \&$ Elliot (1952). The method of Hauser \& Breslow (1955) was used to synthesize $\beta$-hydroxy-( $p$ hydroxyphenyl)propionic acid from $p$-hydroxybenzaldehyde and the product oxidized to form ( $p$ hydroxybenzoyl)acetic acid using acidified $\mathrm{KMnO}_{4}$. The synthesis of $p-\left[1-{ }^{14} \mathrm{C}\right]$ coumaric acid from $p$ hydroxybenzaldehyde and sodium $\left[{ }^{14} \mathrm{C}\right.$ cyanide was carried out by the method of Lapworth \& McRae (1922) and $p$ - $\left[1{ }^{14} \mathrm{C}\right]$ coumaryl alcohol was synthesized from $p-\left[1-{ }^{14} \mathrm{C}\right]$ coumaric acid by the method of Allen \& Byers (1949). In all cases the purity of the synthesized compounds was checked by chromatography and spectral analysis.

The method of Riegel \& Lilienfeld (1945) was used to synthesize $\beta$-ketoadipic acid and its purity checked by melting point determination $\left(119-121^{\circ} \mathrm{C}\right.$, literature value $122^{\circ} \mathrm{C}$ ) and ascending paper chromatography of the 2,4-dinitrophenylhydrazone derivative. The solvents were 2 -methylbutan-2-ol/propan-2-ol/ammonia (sp.gr. $0 \cdot 88$ ) (13:1:6, by vol.) for the first direction and propan-2-ol/ammonia (sp.gr. 0.88$) /$ water $(20: 1: 2$, by vol.) for the second direction. Spots were detected by spraying with $0.1 \mathrm{M}-\mathrm{NaOH}$.

Isolation of intermediates. The fungus was grown on $250 \mathrm{ml}$ medium containing $p$-coumaryl alcohol $(6 \cdot 25 \times$ $10^{-3} \mathrm{M}$ ) in a 11 Erlenmeyer flask under static conditions at $30^{\circ} \mathrm{C}$. The mycelial mat was harvested by filtration, washed with distilled water and used to inoculate $250 \mathrm{ml}$ fresh medium $\mathrm{pH} 5 \cdot 2$, containing $p$-coumaryl alcohol or one of the postulated intermediates, each at $1 \mathrm{mg} \mathrm{ml}^{-1}$. After incubation for $6 \mathrm{~h}$ at $30^{\circ} \mathrm{C}$ on an orbital shaker operating at 100 rev. $\mathrm{min}^{-1}$, the fungal mat was removed by filtration and washed twice with distilled water. The volume of the combined filtrate and washings was reduced to approximately $30 \mathrm{ml}$ by freeze drying, acidified to $\mathrm{pH}$ $2 \cdot 0$ with $2 \mathrm{M}-\mathrm{HCl}$ and extracted three times with diethyl ether. After combining and drying the ether extracts over anhydrous $\mathrm{Na}_{2} \mathrm{SO}_{4}$ the organic phase was evaporated to dryness. The residue was dissolved in ethanol and fractionated by chromatography.

Isolation of radioactive intermediates. A $7 \mathrm{~d}$ old mycelial mat was harvested by filtration, washed with distilled water and resuspended in $10 \mathrm{ml}$ fresh medium. $p-\left[1-{ }^{14} \mathrm{C}\right] \mathrm{Coumaryl}$ alcohol $(2 \mu \mathrm{Ci}, 100 \mu \mathrm{mol})$ was added and incubated at $30^{\circ} \mathrm{C}$ on an orbital incubator $\left(100 \mathrm{rev} . \mathrm{min}^{-1}\right)$. At various time intervals portions of medium were removed, added to hot methanol $(2 \mathrm{ml})$ and the precipitate formed was removed by centrifuging and washed with methanol. The methanolic samples were pooled, dried, acidified to $\mathrm{pH} 2.0$ with $2 \mathrm{M}-\mathrm{HCl}$ and extracted with diethyl ether.

The ethereal extracts were spotted on to triplicate paper chromatograms. One paper was visualized by spraying as described below and the position of the spots on the second paper checked using a strip scanner. The spots were eluted with $2 \mathrm{M}-\mathrm{NaOH}$, acidified with $2 \mathrm{M}-\mathrm{HCl}$ and extracted three times with diethyl ether before drying and counting in a scintillation counter. The identity of the compound was checked by elution from the third chromatograph, mixing portions of the sample with possible intermediates followed by co-chromatography. The melting point was then determined and checked against an authentic sample.

Chromatography. Thin-layer chromatography was carried out on silica gel $\mathrm{G}$ using a solvent of benzene/acetic acid ( $9: 1$, by vol.) (Smith, 1960). Two-way paper chromatography was carried out on Whatman no. 1 paper using the solvent system of Reio (1958). Chromatograms were viewed under UV light to visualize aromatic intermediates. Phenolic compounds were detected as described by Smith (1960), carboxylic acids were detected by spraying with $\mathrm{KMnO}_{4}$ and carbonyl compounds were sprayed with a saturated solution of alkaline 2,4-dinitrophenylhydrazine.

The various intermediates separated by thin-layer chromatography were eluted with $\mathrm{NaOH}$ and the eluates acidified and extracted with diethyl ether. The compounds were purified by thin-layer chromatography, eluted with alkali, acidified, extracted with diethyl ether, dried and recrystallized from hot water. 
Identification of compounds. The melting points of compounds which had been purified by chromatography and recrystallization were obtained separately and also mixed with authentic samples. IR spectra were obtained on a Perkin-Elmer SP200 from samples in nujol. UV spectra were obtained on a Unicam SP800 recording spectrophotometer from samples dissolved in UV ethanol. Mass spectra were obtained using an AEI MS312 spectrophotometer and NMR spectra were obtained on a Perkin-Elmer R32 from samples dissolved in $\mathrm{CDCl}_{3}$.

Isolation of $\beta$-ketoadipic acid. Crude cell-free extracts (approx. $150 \mathrm{mg}$ protein) were prepared in $300 \mathrm{ml}$ $0.1 \mathrm{M}$-sodium phosphate buffer $\mathrm{pH} 7.0$ and stirred at $30^{\circ} \mathrm{C}$. Protocatechuic acid $(3 \mathrm{mmol})$ was added in $50 \mu \mathrm{mol}$ aliquots and samples were then removed and tested for residual protocatechuic acid (Evans, 1947). Incubation was continued for $2 \mathrm{~h}$ after a negative test for protocatechuic acid was obtained.

The product was isolated by the method of Darrah \& Cain (1967), subjected to a Rothera test (Rothera, 1908) and the melting point determined. The 2,4-dinitrophenylhydrazone derivative was prepared and cochromatographed with the 2,4-dinitrophenylhydrazone of an authentic sample of $\beta$-ketoadipic acid using a solvent consisting of 2-methylbutan-2-ol/propan-2-ol/ammonia (sp.gr. 0.88) (13:6:1, by vol.) on Whatman no. 1 paper. Spots were detected by spraying with $0.1 \mathrm{~m}-\mathrm{NaOH}$.

The spectral properties of the isolates were compared with those of authentic $\beta$-ketoadipic acid and the product was estimated by the method of Sistrom \& Stanier (1953).

Identification of $\left[{ }^{14} \mathrm{Clacetic}\right.$ acid. Biogel $\mathrm{P} 10$ was suspended in $0 \cdot 1 \mathrm{M}$-phosphate buffer $\mathrm{pH} 7.0$ and allowed to stand for $1 \mathrm{~h}$ before packing a column $(32 \times 2 \mathrm{~cm})$. The eluant used was $0.01 \mathrm{M}-\mathrm{HCl}$ and samples $(2 \mathrm{ml})$ were adjusted to $\mathrm{pH} 7.0$ with $0.1 \mathrm{M}-\mathrm{NaOH}$ before application to the column.

The column was calibrated with $p$-coumaric acid which was detected in the fractions $(5 \mathrm{ml})$ spectrophotometrically at $310 \mathrm{~nm}$. Maximum elution of acid occurred in fractions 36 and 37 . The column was also calibrated with $\left[1-{ }^{14} \mathrm{C}\right]$ acetic acid $(10 \mathrm{mg}, 0 \cdot 1 \mu \mathrm{Ci})$ adjusted to $\mathrm{pH} 7.0$ with $0.1 \mathrm{M}-\mathrm{NaOH}$, using the same eluant. Maximum elution of $\left[1-{ }^{14} \mathrm{C}\right]$ acetic acid occurred in fractions $27-29$.

Samples consisting of $50 \mu \mathrm{mol} p$-[ $\left.1-{ }^{14} \mathrm{C}\right]$ coumaric acid in $15 \mathrm{ml} 0.025 \mathrm{M}$-phosphate buffer $\mathrm{pH} 7.0$ were oxidized by cell-free extracts (approx. $150 \mathrm{mg}$ protein) for $1 \mathrm{~h}$ at $30^{\circ} \mathrm{C}$ in the presence of $1.0 \mu \mathrm{mol} \mathrm{NAD}$. The reaction was stopped by adding $2 \mathrm{M}-\mathrm{HCl}$ to $\mathrm{pH} 2.0$ and the mixture was extracted twice with diethyl ether. The ethereal extracts were pooled, dried, redissolved in $0.1 \mathrm{M}-\mathrm{NaOH}$ and the $\mathrm{pH}$ was adjusted to 7.0 with $0.01 \mathrm{M}-\mathrm{HCl}$. Samples $(2 \mathrm{ml})$ were applied to the column and eluted with $0.01 \mathrm{M}-\mathrm{HCl}$.

Fractions containing acetic acid were pooled, adjusted to $\mathrm{pH} 7.0$ with $0.1 \mathrm{M}-\mathrm{NaOH}$ and freeze dried. Acetate was detected and characterized by two-dimensional paper chromatography using ethanol/ammonia (sp.gr. 0.88 )/water $(20: 1: 4$, by vol.) and propan-2-ol/ammonia (sp.gr. 0.88$) /$ water $(20: 1: 2$, by vol.) and detected by spraying with bromocresol purple.

Determination of ${ }^{14} \mathrm{CO}_{2}$. Radioactive $\mathrm{CO}_{2}$ evolved from $p-\left[1-{ }^{14} \mathrm{C}\right]$ coumaric acid was determined by the method of Perrin \& Towers (1973). Filtered air was passed through $20 \% \mathrm{KOH}$ to remove the $\mathrm{CO}_{2}$ and then passed through a wash bottle containing sterile water. The $\mathrm{CO}_{2}$-free air was bubbled into a flask containing mycelium removed from $25 \mathrm{ml}$ culture and resuspended in $25 \mathrm{ml}$ phosphate buffer $\mathrm{pH} 5.2$ containing $10 \mu \mathrm{mol}$ $p-\left[1{ }^{14} \mathrm{C}\right]$ coumaric acid. After passage through the culture the air was passed through $10 \mathrm{ml}$ methanolic Hyamine hydroxide. Aliquots of this were removed at intervals and counted in a scintillation counter.

Enzyme assays. The $\mathrm{NAD}^{+}$-linked $\beta$-hydroxy-( $p$-hydroxyphenyl)propionic acid dehydrogenase of the crude cell-free extract was assayed at $30^{\circ} \mathrm{C}$ by measuring the increase in absorbance at $340 \mathrm{~nm}$. The reaction mixture consisted of $\beta$-hydroxy- $\left(p\right.$-hydroxyphenyl)propionic acid $(10 \mu \mathrm{mol}), \mathrm{NAD}^{+}(1 \mu \mathrm{mol})$, crude cell-free extract $(1 \mathrm{ml}$; approx. $10 \mathrm{mg}$ protein) and sodium phosphate buffer $(\mathrm{pH} 8.5,0.1 \mathrm{M})$ to give a final volume of $3 \mathrm{ml}$. At the end of the reaction the samples were pooled and treated with an acidic solution of saturated 2,4-dinitrophenylhydrazine. The brown precipitate obtained was filtered and dried, and its melting point determined both separately and mixed with an authentic sample of the 2,4-dinitrophenylhydrazine derivative of authentic ( $p$-hydroxybenzoyl)acetic acid. The sample was also subjected to chromatography and compared with the authentic 2,4-dinitrophenylhydrazone.

\section{RE S ULTS}

Growth experiments. Glucose $\left(6 \cdot 25 \times 10^{-3} \mathrm{M}\right)$ was a better carbon source for growth of $A$. flavus than $p$-coumaryl alcohol at the same concentration (Fig. 1).

Identification of intermediates. When mycelial mats were suspended in fresh medium containing $p$-coumaryl alcohol and incubated for $6 \mathrm{~h}$, four aromatic compounds were obtained (Table 1). Fewer aromatic compounds were isolated when $p$-coumaryl alcohol was replaced by postulated intermediates as sole carbon source (Table 2). The incubation of boiled mycelium with $p$-hydroxybenzoic acid gave small amounts of $p$-hydroxybenzaldehyde.

Manometric studies. A number of postulated intermediates were oxidized by both whole mycelium and cell-free extracts. These included $p$-coumaric acid, $p$-hydroxybenzoic acid and 


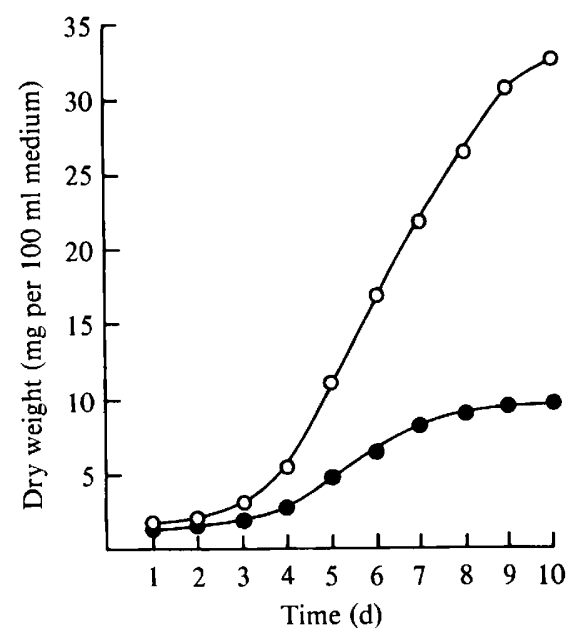

Fig. 1. Growth of $A$. flavus on glucose $(O)$ and $p$-coumaryl alcohol $(O)$ as sole carbon source, each at $6.25 \times 10^{-3} \mathrm{M}$. The organism was grown on $100 \mathrm{ml}$ medium (for composition see Methods) in 1 litre Erlenmeyer flasks at $30^{\circ} \mathrm{C}$ under static conditions.

Table 1. Identity of compounds isolated from medium containing p-coumaryl alcohol as substrate

$R_{F}$ values were obtained on silica gel $\mathrm{G}$ using a solvent of benzene/acetic acid $(9: 1$, by vol.). In each case the IR and NMR spectra were obtained and compared with those of authentic samples.

\begin{tabular}{|c|c|c|c|c|}
\hline Isolate & $\begin{array}{c}R_{F} \\
\text { value }\end{array}$ & $\begin{array}{c}\text { Mol. wt by mass } \\
\text { spectrometry } \dagger\end{array}$ & Melting point $\dagger$ & Identity \\
\hline A & $0 \cdot 10$ & $\begin{array}{c}154 \\
(154)\end{array}$ & $\begin{array}{c}198-200^{\circ} \mathrm{C} \\
\left(200-202^{\circ} \mathrm{C}\right)\end{array}$ & Protocatechuic acid \\
\hline B & 0.21 & $\begin{array}{c}138 \\
(138)\end{array}$ & $\begin{array}{c}210-212^{\circ} \mathrm{C} \\
\left(214-215^{\circ} \mathrm{C}\right)\end{array}$ & $p$-Hydroxybenzoic acid \\
\hline $\mathrm{C}$ & 0.44 & $\begin{array}{c}164 \\
(164)\end{array}$ & $\begin{array}{c}215^{\circ} \mathrm{C} \\
\left(214^{\circ} \mathrm{C}\right)\end{array}$ & $p$-Coumaric acid \\
\hline D & 0.55 & $\begin{array}{l}122 \\
(122)\end{array}$ & $\begin{array}{c}114-116^{\circ} \mathrm{C} \\
\left(117-118^{\circ} \mathrm{C}\right)\end{array}$ & $p$-Hydroxybenzaldehyd \\
\hline
\end{tabular}

$\dagger$ Authentic values are shown in parentheses.

Table 2. Isolation of intermediates from different substrates

\begin{tabular}{lccccc} 
Substrate & \multicolumn{5}{c}{ Compounds isolated } \\
naryl alcohol & $\begin{array}{c}p \text {-Coumaric } \\
\text { acid }\end{array}$ & $\begin{array}{c}\text { Caffeic } \\
\text { acid }\end{array}$ & $\begin{array}{c}p \text {-Hydroxy- } \\
\text { benzaldehyde }\end{array}$ & $\begin{array}{c}p \text {-Hydroxy- } \\
\text { benzoic acid }\end{array}$ & $\begin{array}{c}\text { Protocatechuic } \\
\text { acid }\end{array}$ \\
maric acid & + & - & trace & + & + \\
acid & + & - & trace & + & + \\
roxybenzaldehyde & - & + & - & + & + \\
roxybenzoic acid* & - & - & + & + & + \\
atechuic acid & - & - & trace & + & +
\end{tabular}

* Boiled cells incubated with $p$-hydroxybenzoic acid produced trace amounts of $p$-hydroxybenzaldehyde.

protocatechuic acid (Figs 2 and 3). In both the whole cell and cell-free extract experiments, the uptake of oxygen in the flasks containing catechol was only marginally higher than in the endogenous flasks. 


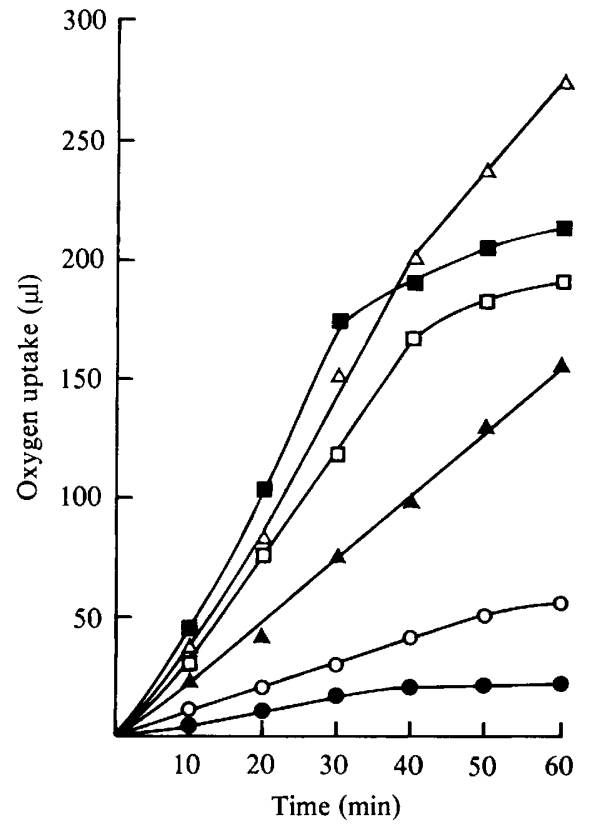

Fig. 2

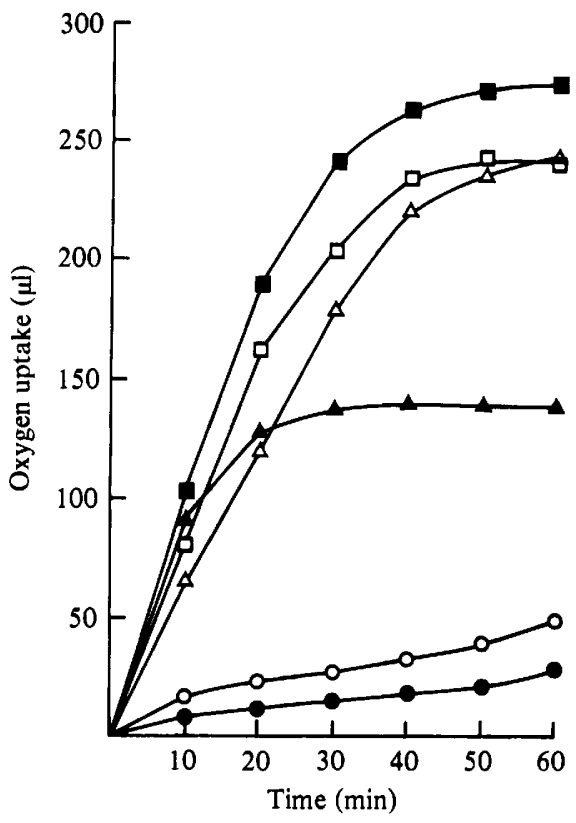

Fig. 3

Fig. 2. Oxygen uptake by mycelium. Each Warburg flask contained a total volume of $3.0 \mathrm{ml}$ made up as follows. The main chamber contained intact mycelial suspension (approx. $10 \mathrm{mg}$ protein) in $1.8 \mathrm{ml}$ phosphate buffer $(0.5 \mathrm{M}, \mathrm{pH} 5 \cdot 2)$. The centre well contained $0.2 \mathrm{ml} 20 \% \mathrm{KOH}$ and a piece of filter paper $(1 \times 1 \mathrm{~cm})$. The reaction was started by tipping $1 \mathrm{ml}$ substrate $(5 \mu \mathrm{mol})$ from the side arm into the main compartment. The temperature of the water bath was $30^{\circ} \mathrm{C}$. Endogenous; $\mathrm{O}$, catechol; $\boldsymbol{\Delta}$, protocatechuic acid; $\Delta, p$-hydroxybenzoic acid; $\square, p$-coumaric acid; $\mathbf{\square}, p$-coumaryl alcohol.

Fig. 3. Oxygen uptake by cell-free extracts. Each Warburg flask contained a total volume of $3.0 \mathrm{ml}$ made up as described in the legend to Fig. 2 except that cell-free extract (approx. $10 \mathrm{mg}$ protein) was substituted for mycelial suspension. - Endogenous; $O$, catechol; $\boldsymbol{\Delta}$, protocatechuic acid; $\Delta$, $p$-hydroxybenzoic acid; $\square, p$-coumaric acid; $\square, p$-coumaryl alcohol.

Table 3. Distribution of radioactive label in the medium after incubation of the mycelium of A. flavus with $p-\left[1-{ }^{14} \mathrm{C}\right]$ coumaryl alcohol

$\begin{array}{ccccc}\begin{array}{c}\text { Incubation } \\ \text { time }(\mathrm{h})\end{array} & \begin{array}{c}p \text {-Coumaryl } \\ \text { alcohol }\end{array} & \begin{array}{c}p \text {-Coumaric } \\ \text { acid }\end{array} & \begin{array}{c}p \text {-Hydroxybenzoic } \\ \text { acid }\end{array} & \begin{array}{c}\text { Protocatechuic } \\ \text { acid }\end{array} \\ 1 & 9768 & 1442 & 0 & 0 \\ 2 & 7535 & 1675 & 0 & 0 \\ 3 & 5172 & 2038 & 0 & 0 \\ 6 & 4316 & 2894 & 0 & 0 \\ & \text { * Corrected for background. }\end{array}$

Radioactive labelling. When $A$. flavus was fed with $2 \mu \mathrm{Ci} p-\left[1-{ }^{14} \mathrm{C}\right]$ coumaryl alcohol, the only radioactively labelled metabolite which could be isolated was $p$-coumaric acid (Table 3 ). Incubation of $p-\left[1-{ }^{14} \mathrm{C}\right]$ coumaric acid with intact mycelium resulted in the evolution of ${ }^{14} \mathrm{CO}_{2}$ after a lag phase of approximately $20 \mathrm{~min}$.

Incubation of the labelled compound with cell-free extracts in the presence of $\mathrm{NAD}^{+}$gave rise to $\left[{ }^{14} \mathrm{C}\right.$ ]acetate which was confirmed by chromatographic analysis (see Methods).

Rapid sampling experiments using $p-\left[1-{ }^{14} \mathrm{C}\right]$ coumaryl alcohol produced two transient radioactively labelled intermediates in amounts too small for analysis. Two possible 


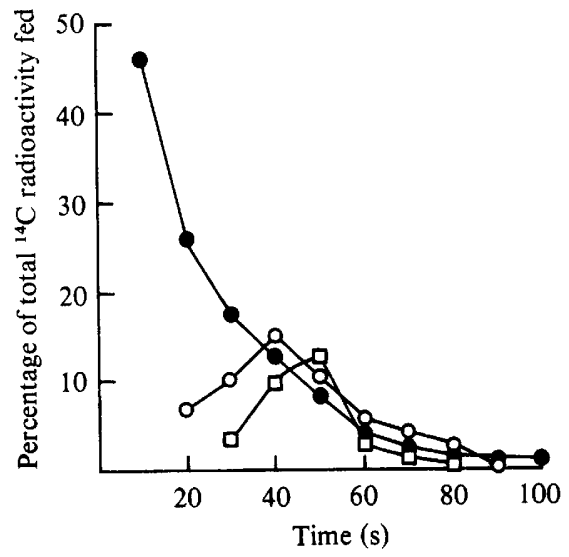

Fig. 4. Rapid sampling of $A$. flavus utilizing $p$-coumaryl alcohol. Mycelium from cultures $7 \mathrm{~d}$ old was suspended in $10 \mathrm{ml}$ fresh medium containing $100 \mu \mathrm{mol} p$-coumaryl alcohol. Unlabelled $\beta$-hydroxy( $p$-hydroxyphenyl)propionic acid and ( $p$-hydroxybenzoyl)acetic acid were added, followed by $1 \mu \mathrm{Ci}$ $p-\left[1-{ }^{14} \mathrm{C}\right]$ coumaryl alcohol; $1 \mathrm{ml}$ samples were removed at $10 \mathrm{~s}$ intervals and added to $2.0 \mathrm{ml}$ boiling methanol. The precipitate was removed by centrifuging and the methanolic samples dried and chromatographed. Samples were purified to constant activity and then counted by scintillation counting. $0, \quad p-\left[{ }^{14} \mathrm{C}\right]$ Coumaric acid; $O, \quad \beta$-hydroxy-( $p$-hydroxyphenyl $)\left[{ }^{14} \mathrm{C}\right]$ propionic acid; $\square, \quad(p$ hydroxybenzoyl) $\left[{ }^{14} \mathrm{C}\right]$ acetic acid.

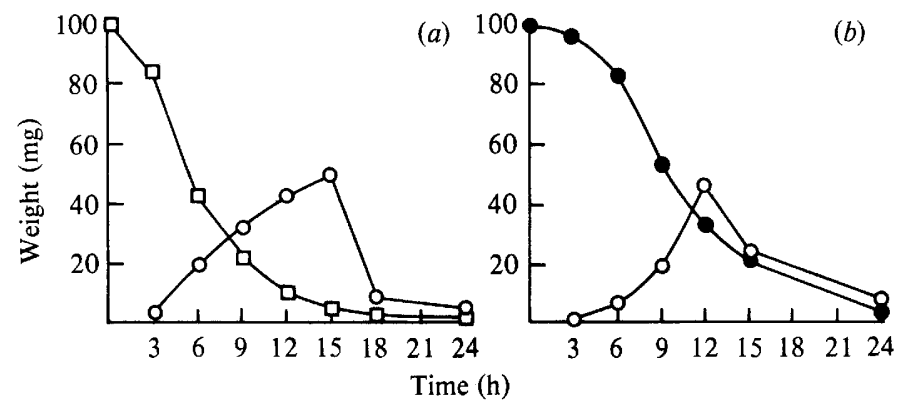

Fig. 5. Synthesis of protocatechuic acid. Mycelium from cultures $7 \mathrm{~d}$ old was resuspended in $100 \mathrm{ml}$ fresh medium containing either $100 \mathrm{mg} p$-coumaric acid $(a)$ or $100 \mathrm{mg}$-hydroxybenzoic acid $(b)$ and incubated for $24 \mathrm{~h}$ at $30^{\circ} \mathrm{C}$. Samples $(10 \mathrm{ml})$ were removed at intervals and extracted with diethyl ether. They were dried, resuspended in methanol and chromatographed in a solvent of formic acid/water (1:49, by vol.). After separation the compounds were assayed spectrophotometrically, $p$ hydroxybenzoic acid $(O)$ at $258 \mathrm{~nm}, p$-coumaric acid $(\square)$ at $310 \mathrm{~nm}$ and protocatechuic acid $(O)$ at $260 \mathrm{~nm}$.

intermediates are $\beta$-hydroxy-( $p$-hydroxyphenyl)propionic acid and ( $p$-hydroxybenzoyl)acetic acid. These compounds were synthesized, their purity checked and $10 \mu \mathrm{mol}$ each added to a mycelial suspension utilizing $p-\left[1-{ }^{14} \mathrm{C}\right]$ coumaryl alcohol. The $\beta$-hydroxy- $(p-$ hydroxyphenyl)propionic acid and ( $p$-hydroxybenzoyl)acetic acid were then reisolated and purified to constant activity by recrystallization. The appearance of radioactive label in these two compounds over a period of time was determined (Fig. 4).

Synthesis of protocatechuic acid. As the levels of $p$-hydroxybenzoic acid and p-coumaric acid fell, protocatechuic acid was synthesized by a mycelial suspension (Fig. $5 a, b$ ). The enzyme $p$-hydroxybenzoate hydroxylase was not assayed in cell-free extracts. 
Enzyme assay. Crude cell-free extracts of $A$. flavus showed $\mathrm{NAD}^{+}$-linked dehydrogenase activity when $\beta$-hydroxy-( $p$-hydroxyphenyl)propionic acid was used as substrate. No activity could be demonstrated when $\mathrm{NADP}^{+}$was added instead of $\mathrm{NAD}^{+}$. When the final products of a number of these assays were mixed and treated with an acidic solution of saturated 2,4-dinitrophenylhydrazine, a 2,4-dinitrophenylhydrazone was formed which had the same melting point and chromatographic properties as that of the 2,4-dinitrophenylhydrazone of an authentic sample of ( $p$-hydroxybenzoyl)acetic acid $\left(100-102^{\circ} \mathrm{C}\right)$.

It was not possible to identify ring cleavage products in any of the whole cell experiments. However, a Warburg experiment utilizing cell-free extracts in the presence of protocatechuic acid showed oxygen uptake (Fig. 3). The size of the experiments was increased, and when cell-free extracts were incubated with $3 \mathrm{mmol}$ protocatechuic acid, approximately $100 \mathrm{mg}$ of a compound which was identified as $\beta$-ketoadipic acid by a positive Rothera test was isolated. Melting point determinations of the isolate $\left(117^{\circ} \mathrm{C}\right)$ compared with that of an authentic sample $\left(118^{\circ} \mathrm{C}\right)$ and of the 2,4-dinitrophenylhydrazone $\left(206^{\circ} \mathrm{C}\right)$ compared with the 2,4-dinitrophenylhydrazone of an authentic sample $\left(206^{\circ} \mathrm{C}\right)$ confirmed its identity. The IR spectrum of the isolated compound was also compatible with its identification as $\beta$-ketoadipic acid.

An assay of the $\beta$-ketoadipic acid and carbon dioxide formed from protocatechuic acid by cell-free extracts showed that the reaction was nearly stoichiometric. Every mole of protocatechuic acid disappearing resulted in the production of $0.96 \mathrm{~mol} \beta$-ketoadipic acid and $1.01 \mathrm{~mol}$ carbon dioxide.

\section{DISCUSSION}

The initial step in the degradation of p-coumaryl alcohol involves its conversion to the corresponding carboxylic acid. Several authors have shown that this takes place via the aldehyde (Sundman, 1964; Liu \& Johnson, 1971; Ratledge, 1978). The free aldehyde ( $p$-hydroxycinnamyl aldehyde) could not be detected in this study although labelled $p$-coumaric acid could be isolated after incubation of the cells with labelled $p$-coumaryl alcohol.

The further conversion of $p$-coumaric acid to $p$-hydroxybenzoic acid could take place by one of two pathways. Several authors have reported that cinnamic acid and related compounds could be converted to the corresponding benzoic acid derivative by a process of $\beta$-oxidation (Henderson \& Farmer, 1955; Henderson, 1961; Zenk \& Muller, 1964; Vollmer et al., 1965). Other workers, however, have reported the non-oxidative shortening of the side chain of such compounds to give the corresponding benzaldehyde derivative which could then be oxidized to the corresponding acid (Toms \& Wood, 1970; Kindl \& Ruis, 1971; French et al., 1976). This pathway would not involve the formation of coenzyme A derivatives. A requirement for coenzyme $A$ derivatives could not be demonstrated during the metabolism of the side chain of $p$-coumaryl alcohol by Aspergillus flavus.

The formation of $\left[{ }^{14} \mathrm{C}\right]$ acetate during the degradation of $p-\left[1-{ }^{14} \mathrm{C}\right]$ coumaric acid gives no indication which of these pathways is operating as they would both give rise to $\left[{ }^{14} \mathrm{C}\right.$ lacetate. Both $p$-hydroxybenzaldehyde and $p$-hydroxybenzoic acid could be isolated after cells had been incubated with $p$-coumaric acid, although only trace amounts of $p$-hydroxybenzaldehyde were found. However, $p$-hydroxybenzaldehyde could be isolated when boiled cells were incubated with $p$-hydroxybenzoic acid. Only $p-\left[{ }^{14} \mathrm{C}\right]$ coumaric acid and not $p$ hydroxy $\left[{ }^{14} \mathrm{C}\right]$ benzoic acid or $\left[{ }^{14} \mathrm{C}\right]$ protocatechuic acid could be isolated and identified after incubation with $p$ - $\left[{ }^{14} \mathrm{C}\right]$ coumaryl alcohol. This is explained by the ${ }^{14} \mathrm{C}$ of the side chain being removed as $\left[{ }^{14} \mathrm{C}\right]$ acetate (Fig. 6).

During rapid sampling experiments, small amounts of two radioactively labelled compounds were obtained which were identified as $\beta$-hydroxy-( $p$-hydroxyphenyl)propionic acid and ( $p$-hydroxybenzoyl)acetic acid. Both of these compounds would be formed during a 


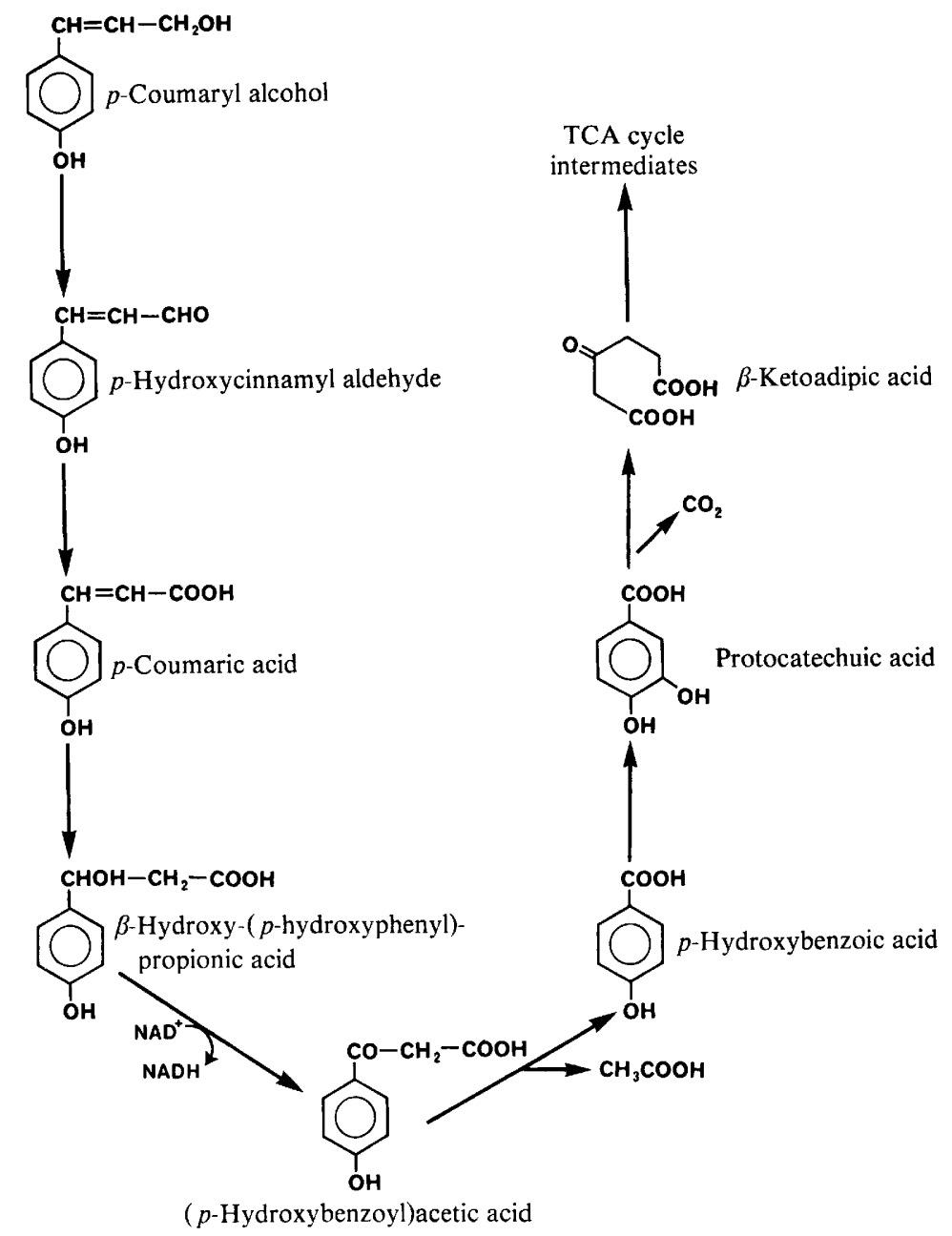

Fig. 6. Proposed pathway for the degradation of p-coumaryl alcohol.

$\beta$-oxidation but only $\beta$-hydroxy-(p-hydroxyphenyl)propionic acid would be formed in the non-oxidative pathway of the type proposed by Toms \& Wood (1970). In addition the $\mathrm{NAD}^{+}$-linked dehydrogenase converting $\beta$-hydroxy-( $p$-hydroxyphenyl)propionic acid to ( $p$-hydroxybenzoyl)acetic acid could be demonstrated in cell-free extracts. This enzyme would not be required in the non-oxidative pathway but carries out an essential step in $\beta$-oxidation. The evidence therefore suggests that $p$-hydroxybenzaldehyde arises from $p$-hydroxybenzoic acid as an artefact of isolation and chromatography, and the conversion of $p$-coumaric acid to $p$-hydroxybenzoic acid involves a $\beta$-oxidation type of reaction.

Incubation of $p-\left[1-{ }^{14} \mathrm{C}\right]$ coumaric acid with intact mycelium produced ${ }^{14} \mathrm{CO}_{2}$ after a lag phase of approximately $20 \mathrm{~min}$, which is presumed to be the time required to convert $\left[{ }^{14} \mathrm{C}\right]$ acetate to ${ }^{14} \mathrm{CO}_{2}$.

The enzyme $p$-hydroxybenzoate hydroxylase was not demonstrated in $A$. flavus grown on $p$-coumaryl alcohol but we have shown the presence of this enzyme and its inducible nature in $A$. flavus grown on mandelic acid (unpublished results).

The results show that protocatechuic acid was synthesized when $p$-coumaric acid and $p$-hydroxybenzoic acid were metabolized by intact mycelium. Protocatechuic acid was also 
metabolized without a lag phase by both whole cells and cell-free extracts, whereas catechol was only metabolized slowly. Protocatechuic acid is the last aromatic compound in the metabolic sequence and ortho or intradiol cleavage by the enzyme protocatechuate 3,4-dioxygenase would ultimately give rise to $\beta$-ketoadipic acid. The various intermediates (Cain et al., 1968) were not isolated but $\beta$-ketoadipic acid could be purified and identified from the reaction mixture. The pathway of degradation of $p$-coumaryl alcohol as shown in Fig. 6 is therefore proposed.

One feature which has not yet been investigated is the low mycelial yield on $p$-coumaryl alcohol (Fig. 1). An examination of the theoretical yield of ATP from $p$-coumaryl alcohol suggests that the cell yield should be somewhat higher than that from glucose. Several explanations are possible and these are being investigated further.

\section{REFERENCES}

Allen, C. F. H. \& Byers, J. R. (1949). A synthesis of coniferyl alcohol and coniferyl benzoate. Journal of the American Chemical Society 71, 2683-2684.

Ander, P. \& Eriksson, K-E. (1978). Lignin degradation and utilization by microorganisms. Progress in Industrial Microbiology 14, 1-58.

Cain, R. B., Bilton, R. F. \& Darrah, J. A. (1968). The metabolism of aromatic acids by microorganisms. Biochemical Journal 108, 797-828.

Cowling, E. B. (1961). Comparative biochemistry of the decay of sweetgum sapwood by white-rot and brown-rot fungi. U.S. Department of Agriculture Technical Bulletin No. 1258.

Darrah, J. A. \& CaIN, R. B. (1967). A convenient biological method for preparing $\beta$-keto-adipic acid. Laboratory Practice 16, 989-990.

DART, R. K. (1975). Long chain fatty acids in spores of Penicillium. Transactions of the British Mycological Society 65, 312-315.

Evans, W. C. (1947). Oxidation of phenol and benzoic acid by some soil bacteria. Biochemical Journal 41, 373-382.

French, C. J., Vance, C. P. \& Towers, G. H. N. (1976). Conversion of $p$-coumaric acid to $p$ hydroxybenzoic acid by cell free extracts of potato tubers and Polyporus hispidus. Phytochemistry 15, $564-566$.

FreUNDENBERG, K. \& NeISH, A. C. (1968). Constitution and Biosynthesis of Lignin. Berlin: Springer-Verlag.

FukUzumI, T. (1980). Microbial metabolism of ligninrelated aromatics. In Lignin Biodegradation, vol. II, pp. 73-94. Edited by T. K. Kirk, T. Higuchi \& H.-m. Chang. Boca Raton, Florida: C.R.C. Press.

Hauser, C. R. \& Breslow, D. S. (1955). Ethyl$\beta$-phenyl- $\beta$-hydroxypropionate. In Organic Syntheses Collective, vol. 3, pp. 408-410. Edited by E. C. Horning. London: Wiley.

Henderson, M. E. K. (1961). Metabolism of aromatic compounds related to lignin. Journal of General Microbiology 26, 155-165.

Henderson, M. E. K. \& Farmer, V. C. (1955). Utilization by soil fungi of $p$-hydroxybenzaldehyde, ferulic acid, syringaldehyde and vanillin. Journal of General Microbiology 12, 37-46.

Higuchi, T. (1971). Formation and biological degradation of lignin. Advances in Enzymology 34, 207-283,
KawaKami, H. (1976). Bacterial degradation of lignin. Mokuzai Gakkaishi 22, 252-257.

KawaKamI, H. (1980). Degradation of lignin-related aromatics and lignins by several pseudomonads. In Lignin Biodegradation, vol. II, pp. 103-125. Edited by T. K. Kirk, T. Higuchi \& H.-m. Chang. Boca Raton, Florida: C.R.C. Press.

KINDL, H. \& RuIS, H. (1977). Subcellular distribution of $p$-hydroxybenzoic acid formation in castor bean endosperm. Zeitschrift für Naturforschung $\mathbf{2 6 8}$, 1379-1380.

KIRK, T. K. (1971). Effects of micro-organisms on lignin. Annual Review of Phytopathology 9, 185210.

Lapworth, A. \& McRaE, J. A. (1922). Syntheses of alkylidenecyanoacetic acids and of substituted succinic acids. Journal of the Chemical Society 121, 1699-1712.

LI, L. \& Elliot, W. H. (1952). Synthesis of 2methyl-1,4-naphtho-quinone-4-C ${ }^{14}$. Journal of the American Chemical Society 74, 4089-4090.

Liv, C. \& Johnson, M. J. (1971). Alkane oxidation by a particulate preparation from Candida. Journal of Bacteriology 106, 830-834.

Oglesby, R. T., Christman, R. F. \& Driver, C. H. (1967). The biotransformation of lignin to humus facts and postulates. Advances in Applied Microbiology 9, 171-184.

Perrin, P. W. \& Towers, G. H. N. (1973). Metabolism of aromatic acids by Polyporus hispidus. Phytochemistry 12, 583-587.

RATLEDGE, C. (1978). Degradation of aliphatic hydrocarbons. In Developments in the Biodegradation of Hydrocarbons, I, pp. 1-46. Edited by R. J. Watkinson. London: Applied Science Publishers.

Reio, L. (1958). A method for the paper chromatographic separation and identification of phenol derivatives, mold metabolites and related compounds of biochemical interest using a reference system. Journal of Chromatography 1, 338-363.

Riegel, B. \& Lilienfeld, W. M. (1945). The synthesis of $\beta$-keto-esters by the decomposition of acylated malonic esters. Journal of the American Chemical Society 67, 1273-1275.

Rothera, A. C. H. (1908). Note on the sodium nitroprusside reaction for acetone. Journal of Physiology 37, 491-494.

Sistrom, W. R. \& Stanier, R. Y. (1953). The 
mechanism of catechol oxidation by $\mathrm{Myco}$ bacterium butyricum. Journal of Bacteriology 66, 404-406.

SмIтH, I. (1960). Chromatographic and Electrophoretic Techniques, vol. I, 2nd edn, pp. 291-298. London: Heinemann.

Stanier, R. Y. \& Ornston, L. N. (1973). $\beta$-Ketoadipate pathway. Advances in Microbial Physiology 9, 89-151.

STICKLAND, L. H. (1951). The determination of small quantities of bacteria by means of the biuret reaction. Journal of General Microbiology 5, 698703.

Sundman, V. (1964). The ability of $\alpha$-coridendrindecomposing Agrobacterium strains to utilize other lignans and lignin related compounds. Journal of General Microbiology 36, 185-201.
Toms, A. \& WooD, J. M. (1970). The degradation of trans-ferulic acid by Pseudomonas acidivorans. Biochemistry 9, 337-343.

Umbreit, W. W., Burris, R. H. \& Stauffer, J. F. (1964). Manometric Techniques, 4th edn, p. 1. Minneapolis: Burgess Publishing Co.

Vollmer, K. O. Reisener, H. J. \& Grisebach, H. (1965). The formation of acetic acid from $p$ hydroxycinnamic acid during its degradation to p-hydroxybenzoic acid in wheat shoots. Biochemical and Biophysical Research Communications 21, 221-225.

ZENK, M. H. \& MUlleR, G. (1964). Biosynthese von $p$-hydroxybenzoesaure und anderer Benzoesauren in hoheren Pflanzen. Zeitschrift für Naturforschung 196, 398-405. 